\title{
Precarising Formality: Understanding Current Labour Developments in Chile
}

\author{
Gonzalo Durán, University of Duisburg-Essen, Germany \\ Karina Narbona, University of Cologne, Germany
}

\begin{abstract}
More than forty years ago, the Chilean economy led the way in a process of flexibilising and privatising a wide range of areas: finance, pensions, education, work and so on. In 1990, with the end of Pinochet's dictatorship, Chile continued to pursue neo-liberal economic policies and maintained the liberal conception of collective labour rights (imposed in 1979). By 2017, labour informality in Chile was among the lowest in South America. Taking these two factors into account (labour regulation that benefited business spending cuts and only "moderate" informality), this article explores the following questions: What are the features of current forms of labour formality in a paradigmatic neo-liberal context like Chile's, and what space does informality occupy? Is labour formality far removed from the kind of vulnerability usually associated with informality? How have formality and informality related to each other in Chile in recent years? We address these questions with mixed methods: a literature review, development of a conceptual proposal, processing of statistical data and case studies. We conclude that a particular kind of labour formality currently prevails in Chile, which we call precarising formality. This concept disputes the traditional idea of labour formality, both because labour regulations lack substance and because they are ineffective, which is, of course, politically produced. We consider it precarising based on an analysis of multiple dimensions of precarity in contexts of theoretical labour formality. The article also describes forms of struggle and resistance by workers' organisations that protest against capitalist action from within this new configuration of labour.
\end{abstract}

\section{KEYWORDS}

formality; informality; labour precarity; Chile

\section{Introduction}

Chile is currently the country with the longest-standing, most mature neo-liberalism in comparative terms (Harvey, 2005; Agacino, 2006). It adopted the first generation of neo-liberal policies before they became a worldwide trend, and it still maintains the core of this design, with several aspects developed even further - namely, speculation with individual pension accounts, the privatisation of state companies, labour flexibilisation, targeted public spending and unrestricted trade liberalisation (Gárate, 2012; Fischer, 2017). Chile’s long period of exposure to neo-liberal policies makes it fertile terrain for studying and understanding current labour trends and some of the organic forms of contestation that have arisen.

This article seeks to answer the following research questions: What are the features of current forms of labour formality in a paradigmatic neo-liberal context like Chile's, and what space does

Global Labour Journal, 2021, 12(3), Page 206 
informality occupy? Is labour formality far removed from the kind of vulnerability usually associated with informality? How do formality and informality relate to each other in Chile?

Conceptually, this article takes a broad approach to assess labour dynamics beyond access to institutional coverage (which defines formal work) and the duality between the formal and the informal. Our central argument is that a particular kind of labour formality prevails today, which we call precarising formality. This concept disputes the traditional idea of formality, because labour regulations both lack substance and are ineffective. We call it precarising based on an analysis of precarity in its multiple dimensions and in contexts of theoretical labour formality. We also discuss forms of struggle and resistance by workers' organisations that protest capitalist action within this new configuration of labour.

We have used a mixed methodology for this research. We develop an analysis and conceptual proposal of formality and precarity and its multiple dimensions, taking up our own previous formulations and giving them greater substance. We also offer an empirical analysis to connect this conceptual framework to a situated interpretation. This includes a statistical analysis of surveys on employment and working conditions and a review of the related literature.

In the next section, we contextualise the recent economic and labour changes both globally and locally. In the third section, we present our analytical model of new trends and precarising formality. The fourth section then offers an empirical analysis for Chile following our proposed conceptual interpretation. In the fifth section, we present responses to precarising formality, and finally, we offer a synthesis and final reflections.

\section{Recent Economic and Labour Changes at the Global and Local Levels}

The issue we address here is related to changes that go beyond the local, changes that are a part of global trends that frame the history of the present. The precarity we see today is tied to forms of sustaining business profits that emerged as a response to the 1970s economic crisis - a crisis ushered in by the oil price shock, but ultimately caused by profound conditions that hindered the reinvestment of surplus capital (Harvey, 2011).

The political way out of this crisis entailed abandoning the gold standard, focusing on practices allowing maximum business freedom, dismantling what were considered to be rigid social commitments and labour rights (Harvey, 2005; Streeck, 2014). The transformation also included the reorientation of domestic economies towards greater integration to external markets and a redeployment of transnational economic groups (Dockes and Rosier, 1981). What followed was a new dynamics of market expansion through multiple forms that re-established primitive accumulation (Harvey, 2003; Dörre, 2010). These changes have coincided with an increase in rentier, extractivist and speculative activities and, in the case of the last, financial exaction through the pension system and the credit system - a credit system that became increasingly overpowering for households, given the containment of direct wages and the privatisation of the social wage (Lapavitsas, 2009).

In this "flexible regime of accumulation", capital takes advantage of its mobility to choose between technologically and organisationally advanced forms of production and "older systems of domestic, artisanal, familial (patriarchal) and paternalistic ... labour" (Harvey, 1992: 152). One of the characteristic features of this mode of accumulation is, precisely, the high degree of eclecticism in its labour practices. Thus, like never before, informal and other forms of precarious labour became part of the most modern formal capitalist sectors. In turn, forms of work have emerged that blur the legal boundaries of dependent employment and externalise risks (such as the 
"entrepreneurship" of the so-called gig economy).

The Latin American working class - the "class-that-lives-from-labour" (Antunes, 1999, 2012) - has confronted the changes imposed by global capitalist restructuring under challenging circumstances. Markets have been flexibilised, though with dissimilar national trajectories, and certain types of employment that resembled so-called standard employment have lost ground (ILO, 2016). Among young people, women and low-skilled workers, employment with temporary employment agencies has started to play a growing role (CSA/CSI, 2013). Nonetheless, a high level of industrial development and social and labour security were never the norm for the world of work in this region (Marini, 1991; Portes, 1995). Thus, while in core countries the concept of precarity has dominated the debate amidst a regression towards the conditions preceding the welfare state (Reinprecht, 2011), in Latin America, like in Africa, the lack of labour protection has been more continuous, and has long been studied since the debate on the informal sector (Prebisch, 1950; ILO, 1972; Tokman, 1995).

Today, in any case, the regional context in Latin America seems to present a double phenomenon: along with the classically studied informal sector, forms of informality and precarity are emerging that, though not entirely similar to those of the Global North, are indeed related to contemporary flexibilisation and include the formal sector.

While unprotected employment and high levels of structural unemployment are common in the region, Chile is somewhat peculiar in that its rentier, extractivist and service-based economy has produced one of the lowest levels of informality in the region (Bensusán, 2016; Fischer, 2017). Noteworthy in this respect is that Chile's economy has always been anchored in low-risk activities: historically, it revolved around its enclave mining economy and in commercial and financial activities, and for a long time it took political advantage of an agricultural sector that, while not very prosperous, was the source of significant employers' power (Faletto, Ruiz and Zemelman, 1972). In fact, farming concentrated the majority of the private labour force, and in 1964 the agricultural sector still accounted for 27 per cent of private sector employment. Leading up to the 1970s, industrialisation and agrarian reform shaped up as promising economic options for capitalism in Chile, while political conciliation appeared effective as a means to regulate social conflict. On both counts, the electoral victory of the socialist Unidad Popular (Popular Unity) government (1970-1973) challenged these seemingly robust economic and institutional arrangements, accelerating agrarian reform and increasing spaces for popular participation, among other aspects.

After the 1973 coup d'état, the doors of the economy were flung wide open to the external market. There was an agrarian counter-reform (though it did not reinstate the old bacienda system), new mechanisms were introduced for appropriating rents from natural resources, the country was deindustrialised, state-owned companies and services were privatised, and workers' rights and those of citizens in general were reconfigured.

The replacement of the public pension system with a private system of individual capitalisation accounts, implemented in 1981, is paradigmatic for the issue of interest here. Also of significance was the reformulation of labour regulations, which took two forms: the flexibilisation and deregulation of the individual employment relationship, and the sharply increased rigidity and atomisation of collective labour relations (Rojas, 2007: 202). With respect to changes to the individual employment relationship, the employer was allowed to freely dismiss workers with only limited severance compensation for years of service (1978), and the previous prohibition preventing companies from subcontracting their main and permanent activities to third parties was eliminated, permitting subcontracting at all levels (1979). With respect to changes to collective 
labour relations, the new regulations - included in the well-known Plan Laboral (Labour Plan) of 1979 - further constrained union aims, as did other disorganising aspects, ultimately benefiting the depoliticisation of working-class struggles. These new regulations permitted collective bargaining at the enterprise level only, removing all bargaining at the level of the branch of activity. They also allowed striking workers to be replaced and permitted labour union dualism (Narbona, 2015a).

These changes were not undone with the return of democracy, though there have been some modifications. In the early 1990s (1990-1993), the country went from a system of free dismissal to a system of dismissal with cause, which permits the vague grounds of "company reasons" for terminating an employment contract (Article 161 of the labour code). Subcontracting and temporary agency work were regulated in 2007 , establishing the joint liability of the parent company if the subcontractor fails to pay. However, the ability to outsource the parent company's main or permanent functions was not curtailed.

Furthermore, in 2001, multifunctional, part-time and apprenticeship contracts were included as formal and flexible modes of hiring. Collective rights have undergone the fewest transformations, and the pillars of the Plan Laboral remain, though, notably, the Union Federations have been legalised, forms of protecting union autonomy have been established and the attributes of the Labour Directorate in relation to anti-union practices were strengthened. In the labour reform implemented in 2017, other clauses were added, with significant implications for the right to strike, further discussed below. Finally, in terms of pensions, state resources were increased for the poorest while maintaining the pillar of individual capitalisation and without dismantling the basic structure of a private model. There is currently an ongoing debate about what a future pension system should look like.

The new and inherited forms of institutional arrangement described above, in their interconnections with productive restructuring itself and with the new dynamics of business organisation, have led to a certain ambivalence in the country: positive macroeconomics, but a high degree of job transience, few social guarantees and widespread wage insufficiency - even in formal jobs - along with overwhelming household economic dependency expressed in debt (Narbona and Páez, 2014; Durán and Kremerman, 2020).

These characteristics are concomitant with three other notable features, each with their particularities, that global agencies like the International Monetary Fund (IMF, 2014) have actively promoted: i) an extremely open export economy; ii) a subsidiary state with minimal union interference; and iii) a high degree of financialisation, facilitated by the credit system and pension system.

\section{Labour Informality and Precarising Formality}

Labour informality and precarity are the concepts most closely related to the conceptual development that forms the basis of our analysis here. In the Chilean case, the agenda for the range of issues we discuss in this paper dates back mainly to when the Regional Employment Programme for Latin America and the Caribbean (PREALC) established its influence at the regional level with a debate about the dual labour market and productive heterogeneity. The Economic Commission for Latin America and the Caribbean (ECLAC) is the heir to this approach.

We begin by discussing the kind of distinctions presented early on and then move on to discuss later developments, including, lastly, our own analysis of precarising formality. 


\section{Informality}

The concept of informality was first discussed in 1971 in two research projects carried out in Ghana and Kenya (Charmes, 2019). In Latin America, its use became popular in the 1980s through the PREALC under the International Labour Organization (ILO).

The informal sector was generally considered a low-productivity, under-registered area in which a large part of the population not absorbed by more modern activities was able to make a living either through low-skilled self-employment or informal employment in microenterprises requiring little access to capital or technology. The focus of attention was on these other forms of self-support that were seen as marginalised and associated with greater economic insecurity. Over time, the study of informality began to shift from a focus on these productive units to an analysis of unprotected work in general. The new focus has been more sensitive to statistical analysis and, equally important, has put the full set of labour relations into perspective. Based on the recommendations coming out of the International Conferences of Labour Statisticians (ICLS), the ILO shifted its approach to focus on the lack of protection, applying a framework known as the Ralf Hussmanns model (ILO, 2013).

In the particular case of Chile, official measures of informal occupation ${ }^{1}$ only began in $2017,{ }^{2}$ adopting the operational framework promoted by the ILO.

Informality can be measured based on two simultaneous phenomena: the informal sector (ICLS, 1993) and informal employment (ICLS, 2003). While the informal sector is determined based on the "firm's situation" (lack of accounting records and lack of a registered business name for paying taxes, among others), informal employment is based on the "job characteristics", where the attributes of the legal employment relationship are of relevance (with the most defining factors being a written contract and the payment of social security contributions). Using a Hussmannsstyle statistical method, then, informality corresponds to a combination of all those situations in which the phenomenon occurs, whether at the level of the sector or the job.

Informal occupation is analysed by occupational category, as shown in Table 1.

Table 1: Categories of informal occupation adopted in Chile

\begin{tabular}{|l|l|}
\hline Category & Description \\
\hline $\begin{array}{l}\text { Self-employed and } \\
\text { freelancers }\end{array}$ & $\begin{array}{l}\text { The formality of their occupation depends on the formality of the } \\
\text { economic unit they own. Their occupation is considered informal if their } \\
\text { firms or businesses are informal. }\end{array}$ \\
\hline Employees & $\begin{array}{l}\text { Their occupation is informal if their employment relationship is not } \\
\text { subject to national labour legislation (social protection and labour } \\
\text { benefits). }\end{array}$ \\
\hline Domestic service & $\begin{array}{l}\text { They do not belong to either the formal or informal sectors, as their tie to } \\
\text { their employer's household is direct. However, they can be classified as } \\
\text { informal workers if their employment relationship is not subject to labour } \\
\text { legislation. }\end{array}$ \\
\hline Unpaid family workers & $\begin{array}{l}\text { They are considered informal regardless of whether they work in a formal } \\
\text { or informal productive unit. }\end{array}$ \\
\hline
\end{tabular}

Source: INE (2017), free translation.

\footnotetext{
${ }^{1}$ Calculated by the National Institute of Statistics (INE) through the National Employment Survey (ENE).

${ }^{2}$ Previous studies analysing informality use different definitions. See FLACSO (2017).
} 
This classification allows the categories to overlap (informal employment and informal sector), thus addressing the analytical challenge posed by labour flexibilisation, in line with the prevailing trend in labour studies in recent decades.

Indeed, along with an analysis of labour markets divided between the formal and the informal, diverse authors have been contributing to a broader field of research with respect to employment quality, so-called non-standard jobs and precarity in its multiple forms (Neffa, 1985, 2010; Rodgers and Rodgers, 1989; Standing, 1999, 2011; De la Garza, 2000; ILO, 2001; Castel, 2003, 2004; Kalleberg and Vallas, 2018). This has entailed a move from unidimensional analyses of the presence of an employment contract and the receipt of social security contributions to analyses that take into account, as Neffa (1985) suggested early on, that formal employment can also be precarious.

Several authors have written about these issues in Chile. Recent research has looked at nonstandard jobs (Gálvez, 2001), employment quality (Sehnbruch, 2013), informal employment (Sáez, 2013) and, in general, labour precarity and its effects (Agacino and Echeverría, 1995; Espinosa et al., 1997; Echeverría and López, 2004; Julián, 2017, 2018; Vives-Vergara et al., 2017; Blanco and Julián, 2019; Vives, González-López and Benach, 2020).

Multidimensional investigations of precarity have been gaining ground, and they have started to pay more attention to the vagueness and opacity of the labour insertions under supposed institutional protection, particularly with surveys designed specifically to dig deeper beneath the surface (Vives-Vergara et al., 2017; Vives et al., 2020). However, progress can also be made with other sources of official data. Blanco and Julián (2019), for example, conduct a kaleidoscopic analysis of precarities using records of formality and informality from the National Socioeconomic Characterisation Survey (CASEN).

Research has problematised a heterogeneous and complex reality, gathering varied evidence, but this can still be complemented. For example, in the specific social security dimension, one can go beyond assessing the presence of health and pension contributions to examining their characteristics (including the amounts offered). In the dimension of job stability, one can go beyond testing the existence of an open-ended contract and discuss this type of contract's actual duration. In our opinion, in the context of liberalised economies, and especially with Chile's sociotechnological configurations, the current condition of formality requires further fine-tuning of approaches and measurements, even if the latter are difficult to complete from a single source. In this endeavour, we first offer a theoretical definition of precarising formality and then carry out an empirical exploration of the different dimensions we propose. We use a range of sources of official data and literature to capture the complexity of the phenomenon.

\section{Precarising formality}

Precarising formality is the condition of formal yet precarious employment. The term "precarising" also implies movement: the action of a formality that creates precarity. With this terminology, our intention is to include in our studies of formality a debate about a diverse range of precarities in the world of work, as well as their expressions and sources, thereby seeking a more complex prism than that of the formal/informal duality.

We have outlined the idea of precarising formality in previous publications (Durán, 2012, 2015; Fundación SOL, 2015). Here, we further specify the concept and give it greater substance. The notion of precarising formality aligns with De la Garza's $(2017,2018)$ ideas about precarisation and is useful to address some of the shortcomings in the conceptualisation of new informality associated with ICLS conferences. For De la Garza, one of the key problems with the idea of the new informality - that is, forms of informality that have expanded to the formal sector of the 
economy - is that it attempts to capture very different realities under the same umbrella. This stretch of the term blurs important differences between labour practices in cutting-edge sectors and sectors in which capitalist relations are not fully constituted. It also neglects the study of the productive system and the analysis of the specificity of peripheral capitalism, whose importance has already been established in the classical sectoral perspective. In this sense, we agree with De La Garza on the need to rethink formality and informality, beyond the operational definitions of the words, in dialogue with the notion of precarity, and considering the different technical and organisational configurations of the work process that have emerged in the history of capitalism. In our view, the notion of precarising formality is useful to address these issues. Having said that, the category of informality is still valuable in accounting for the pressing problem of the denial of labour rights within the formal sector. But it should not be the only analytical resource. Instead, it should be situated in the context of the broader phenomenon of precarity.

We develop a brief outline of a model, showing the internal relations and their manifestations. We propose three interrelated types of labour insertion: non-precarious formality, precarising formality and informality. This last type - informality - currently includes both emergent and classical forms though it would be best to address each issue separately in the future. Furthermore, we assume that multiple precarities tend to be present within the category of informality.

Figure 1 describes the relationships between the different types of labour insertion through which people can enter labour markets. The arrows show a dynamic circuit where, in theory, there are flows in every direction (assuming that non-precarious formality can, in a very limited way, occur in capitalism ${ }^{3}$ ). In reality, however, the upward flows - those of informality (I) towards nonprecarious formality $(\mathrm{F})$ and of precarising formality $(\mathrm{PF})$ towards non-precarious formality $(\mathrm{F})-$ occur less and less, while the flow between precarising formality and informality is abundant, especially among the most impoverished.

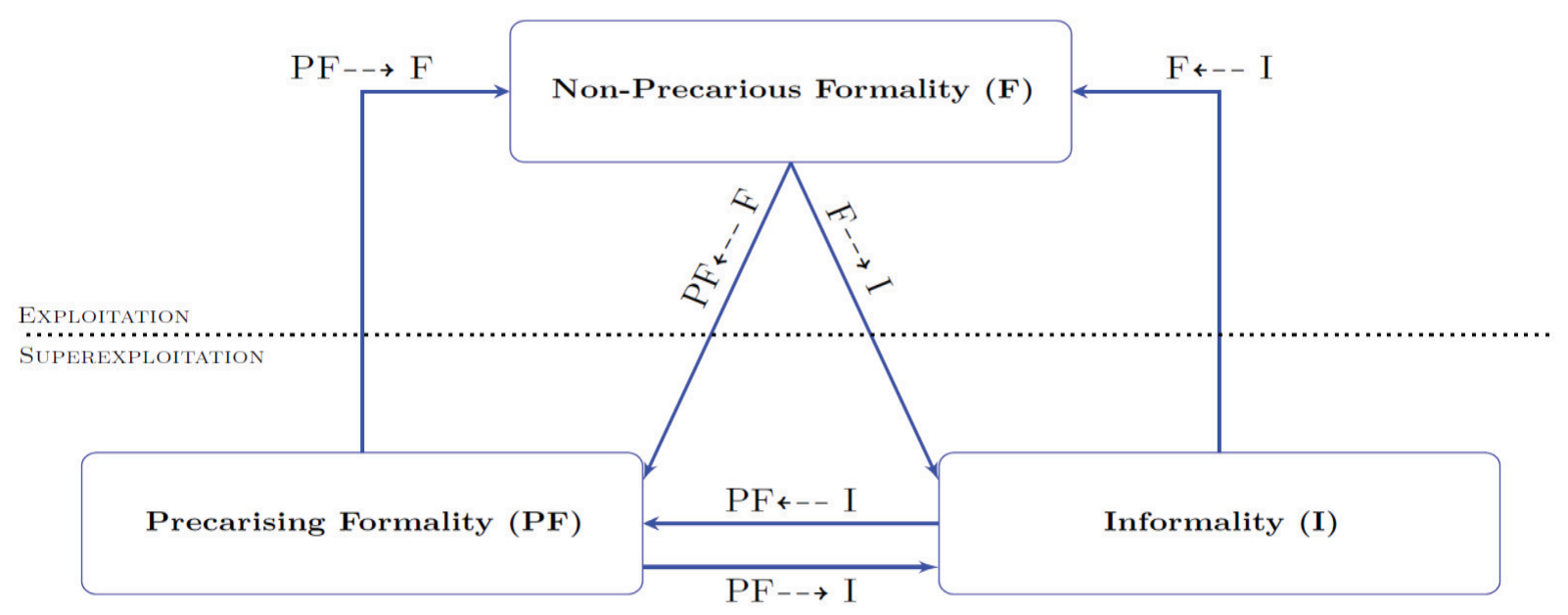

Source: Created by the authors.

Figure 1: Non-precarious formality $(\mathrm{F})$ - precarising formality $(\mathrm{PF})$ - informality (I)

\footnotetext{
${ }^{3}$ Workers with a considerable amount of power and sufficient levels of social, employment and wage security for their sustained reproduction over time have primarily been seen in central countries.
} 
These categories also connect to other concepts. In the view we propose, non-precarious formality is considered to be no stranger to the exploitation of the labour force as unpaid surplus value, while informality and precarising formality are more related to the issue of superexploitation. Following Jaime Osorio's (1975: 9-13) interpretation, super-exploitation is understood as related to the premature exhaustion of the workers, the corporate appropriation of their consumption fund and, in general, the "violation of the set of conditions necessary for the production and reproduction of the workforce".

Super-exploitation is becoming more widespread, overflowing the space of peripheral countries for which it was originally conceived. In this sense, Adrián Sotelo (2003: 2), taking up Mauro Marini's formulations, says that "super-exploitation, as capital's system of exploitation in dependent and underdeveloped societies, is also becoming a system of exploitation of the labour force in the developed capitalist countries".

Having said this, we must now clarify what we understand as precarity, starting once again from our previous publications (Narbona, 2015b, 2016). Labour precarity here is understood in terms of jobs that threaten the sustainability and reproduction of the labour force. It is directly related to super-exploitation and is considered to be a continuous, rather than binary, phenomenon.

Based on this approximation, jobs can be precarious in one or several dimensions. Without creating a comprehensive indicator, ${ }^{4}$ a systematic analysis can account for this multidimensionality separately, identifying six dimensions related to the types of contracts and conditions in the labour process: job instability, social insecurity, wage inconsistency, lack of transparency regarding the identity of the employer, occupational risk and lack of power.

We illustrate how precarity occurs in formal employment, even in permanent positions. We provide examples of features that are present in more than one dimension: ${ }^{5}$

i) job instability

a. formal employment with a permanent contract, in countries with laws facilitating dismissal

b. formal employment with a fixed-term or temporary contract

ii) social insecurity

a. formal employment with payment of health and pension contributions or functioning unemployment insurance, in countries with incomplete or ineffective social security systems

iii) wage inconsistency ${ }^{6}$

a. formal employment with a permanent contract in countries with laws facilitating dismissal

b. formal employment with highly variable pay

c. formal employment paid less than cost of reproduction

\footnotetext{
${ }^{4}$ Ultimately, points could be given to each dimension to calculate a cumulative index of precarity, but such an aggregate index is beyond the scope of this article, as the components involved are dissimilar and proper weighting would be required. Without correct weighting, for example, professionals with unstable contracts yet with sufficient margins of savings to withstand periods of unemployment could be ranked as similarly precarious to workers with a certain degree of stability though clearly poor.

${ }^{5}$ We do not intend to build a synthetic indicator but to present different indicators related to the various dimensions of precarity. That is why examples can be part of one or more dimension (see footnote 6).

${ }^{6}$ Inconsistency refers here to at least two conditions: i) wage unpredictability, or ii) predictability with very low wages.
} 
iv) lack of transparency regarding the identity of the employer

a. formal employment in firms artificially divided into " $n$ " legal entities

b. formal employment subject to triangular employment relationships (e.g., subcontracted)

v) occupational risk (physical/psychological)

a. formal employment subject to long workdays

b. formal employment with high level of functional variety, intensity and/or arbitrariness

c. formal employment with highly variable pay ${ }^{7}$

d. formal employment in positions with scarce level of autonomy

vi) lack of power

a. formal employment not unionised and/or lacking collective agreements

b. formal employment unionised and/or with collective agreements, in countries where these institutions are weak (union-limiting law)

c. formal employment in positions with low levels of autonomy (e.g. low-skill monotonous jobs, lack of opportunities for innovation, and working under constant surveillance)

Not all of these manifestations of precarity are new, and there are precarities that are intrinsic to capitalism, but several are currently more widespread than they were in the recent past. In light of this approach, we identify the emergence of situations in which there are people who, despite having standard employment (a permanent contract and contributions), are also affected by precarity because they remain an easy target for dismissal, they have no real social security even when they contribute (a weakness of this labour right), they have a diffuse employer (due to subcontracting, the artificial fragmentation of companies to minimise labour and social security obligations), or they have low wages, little power, etc. This is related to precarity being induced by institutions themselves, producing a precarising formality (Narbona, 2015b: 26).

How does this interpretive framework behave in light of Chile's long-standing experience with neo-liberalism? With this question in mind, the following section will focus on precarising formality (the left bottom half of Figure 1). In it, we will consider the six dimensions discussed above. At the end of the section, we will address the relationship between precarising formality and informality (the right bottom half of Figure 1), using a case study to illustrate our argument. In the last section of the article, we will bring attention to the potential of union mobilisation as a mechanism to reduce precarity (an upward movement toward the top half of Figure 1).

\section{Precarising Formality in Contemporary Chile}

Chile is a country with close to 19 million inhabitants, of which 15.4 million are of working age. Of these, 58 per cent are actually employed (ENE, 2019). ${ }^{8}$ The labour participation rate - that is, the proportion of people who participate in the job market (whether employed or unemployed) out of all those fifteen years of age and older - is 62.9 per cent. There are marked differences by sex, with a participation rate of 48.9 per cent among women and 73.4 per cent among men. Open unemployment is 7.3 per cent.

\footnotetext{
${ }^{7}$ Salary scales lacking transparent benchmarks which are also established unilaterally by the employer. This kind of unpredictability can have serious impacts on mental health.

${ }^{8}$ Pre-pandemic figures. Unless otherwise stated, all data in this section are from ENE (2019).
} 
Paid employment comprises 74 per cent of all work in Chile and includes people who work for private and public firms, for the state and for private homes (in which case 98 per cent are women). If we break this employment down by economic activity, the branches associated with the tertiary sector of the economy represent almost 70 per cent of total employment, with commerce among the most relevant. Of the activities in the primary sector, mining has always been highly significant in terms of its contribution to GDP, though it accounts for only 1.4 per cent of jobs. Finally, and returning to paid employment, Chile stands out with a high percentage of temporary jobs (26 per cent).

In terms of informality, measured using an adaptation of the Hussmanns framework, Chile's informal employment reaches 27.4 per cent (ENE, 2019) and is far from being a mere anomaly.' Salaried employment also includes considerable levels of informality, close to 16.5 per cent, and women experience a higher degree of informality than men. At the same time, using a simple estimate of informal employment (that is, considering only the existence of pension contributions) to allow a socioeconomic comparison over time, informal employment in the first quintile of income rose from 48.4 per cent in 1992 to 55 percent in 2017, while in the fifth quintile it dropped from 33.5 per cent to 21.4 per cent, 53 per cent of which is associated with professional positions (CASEN, 2017). In other words, informal employment has increased sharply among the poorest. At the same time, informality in Chile, while significant, is currently among the lowest in the region, and in this context the country seems like a model of formalisation.

Now, as we have suggested in theoretical terms, a significant fraction of labour formality presents clear characteristics of being what is, in fact, a precarising formality. Below we offer an empirical presentation for which we employ a mixed methodology, including an analysis of previously processed data, some original calculations and a review of empirical literature (see Table 2). In each dimension we present a global statistical overview, seeking a view of the whole, as well as, where appropriate, specific cases for the purpose of illustration.

The first dimension, job instability, can be analysed as a function of temporary contracts and by examining how indefinite the so-called permanent contracts actually are. To do this, we processed information from the unemployment insurance database, a registry with information on all labour contracts signed from 2002 to date. Each individual has a record with all the employment contracts they have had, including their type and duration.

The results show that as of October 2018, half of all permanent contracts lasted less than fifteen months. This confirms our hypothesis that the problem of instability is not only present in cases of temporary employment (fixed-term contracts). It also exists in institutions considered "normal or typical", which would suggest a certain continuity over time, yet in the best of cases translates in practice into short-term relations, thus constituting a spurious guarantee of stability. Among the many factors that might explain this volatility, two seem the most convincing. The first is the ease with which employers can dismiss employees, justifying the dismissal on the grounds of company needs; this excuse is used for dismissals even within the first year, avoiding the need to pay severance compensation for years of service (López, 2008). The second factor is systemic and is endogenously related to the working conditions (beyond this particular dimension). High turnover can be an avoidance mechanism in the face of harsh conditions. In many cases, workers quit to seek other work, thinking they can find improved material benefits and well-being. The evidence indicates that, in practice, 54 per cent of those who change jobs secure increased wages (Albagli et al., 2018).

\footnotetext{
${ }^{9}$ Estimates based on a more complex construct yield higher numbers. See Sáez (2013).
} 
Table 2. Precarising formality in Chile. Global results based on empirical evidence.

\begin{tabular}{|c|c|c|c|}
\hline Dimension & Indicator & Result & Source \\
\hline \multirow{2}{*}{ i) Job instability } & \multirow{2}{*}{$\begin{array}{l}\text { Duration of work } \\
\text { contracts }\end{array}$} & $\begin{array}{l}\text { Permanent contracts: } \\
50 \% \text { last less than } 15 \\
\text { months. }\end{array}$ & \multirow{2}{*}{$\begin{array}{l}\text { Our calculations, } \\
\text { based on data from } \\
\text { the Chilean } \\
\text { Pensions } \\
\text { Superintendency } \\
2018\end{array}$} \\
\hline & & $\begin{array}{l}\text { Fixed-term contracts: } \\
50 \% \text { last less than } 4 \\
\text { months. }\end{array}$ & \\
\hline \multirow{3}{*}{$\begin{array}{l}\text { ii) Social } \\
\text { insecurity }\end{array}$} & $\begin{array}{l}\text { Sufficiency of } \\
\text { pensions }\end{array}$ & $\begin{array}{l}\text { In December } 2019,50 \% \\
\text { of self-financed } \\
\text { pensions were below the } \\
\text { poverty line for single- } \\
\text { person households. }\end{array}$ & $\begin{array}{l}\text { Gálvez and } \\
\text { Kremerman (2020) }\end{array}$ \\
\hline & \multirow{2}{*}{$\begin{array}{l}\text { "Median" self- } \\
\text { financed replacement } \\
\text { rate of future retirees } \\
(2025-2035) .\end{array}$} & $\begin{array}{l}\text { Women with more than } \\
33 \text { years of } \\
\text { contributions: } 31 \% \text {. }\end{array}$ & \multirow{2}{*}{$\begin{array}{l}\text { Comisión Pensiones } \\
\text { (2015) }\end{array}$} \\
\hline & & $\begin{array}{l}\text { Men with more than } 33 \\
\text { years of contributions: } \\
42 \% \text {. }\end{array}$ & \\
\hline $\begin{array}{l}\text { iii) Wage } \\
\text { inconsistency }\end{array}$ & $\begin{array}{l}\text { Median wage among } \\
\text { formal workers }\end{array}$ & $\begin{array}{l}50 \% \text { of "formal" } \\
\text { workers earn less than } \\
\text { US } \$ 631 \text { a month, below } \\
\text { the family poverty line } \\
\text { for a typical household } \\
\text { in Chile. }\end{array}$ & $\begin{array}{l}\text { Our calculations, } \\
\text { based on CASEN } \\
(2017)\end{array}$ \\
\hline $\begin{array}{l}\text { iv) Lack of } \\
\text { transparency in } \\
\text { regard to the } \\
\text { identity of the } \\
\text { employer }\end{array}$ & $\begin{array}{l}\text { Employees in external } \\
\text { companies }\end{array}$ & $\begin{array}{l}32 \% \text { of the workers } \\
\text { covered by the labour } \\
\text { code who work in large } \\
\text { companies are employed } \\
\text { through external } \\
\text { companies. }\end{array}$ & $\begin{array}{l}\text { Our calculations, } \\
\text { based on ENE } \\
(2019)\end{array}$ \\
\hline \multirow[t]{2}{*}{$\begin{array}{l}\text { v) Occupational } \\
\text { risk (physical/ } \\
\text { psychological) }\end{array}$} & Multifunctionality & $\begin{array}{l}74 \% \text { of contracts } \\
\text { stipulate carrying out } \\
\text { multiple jobs or tasks } \\
\text { according to the } \\
\text { company's needs. }\end{array}$ & $\begin{array}{l}\text { Our calculations, } \\
\text { based on ENETS } \\
(2010)\end{array}$ \\
\hline & Variable pay structure & $\begin{array}{l}3 \text { out of } 10 \text { workers say } \\
\text { that most (or all) of their } \\
\text { pay is variable. }\end{array}$ & ENETS (2010) \\
\hline \multirow{3}{*}{$\begin{array}{l}\text { vi) Lack of } \\
\text { power }\end{array}$} & Union presence & $\begin{array}{l}\text { In } 93.7 \% \text { of companies } \\
\text { with more than } 10 \\
\text { workers, there is no } \\
\text { union. }\end{array}$ & ENCLA (2019) \\
\hline & Rate of unionisation & $\begin{array}{l}\text { The rate of unionisation } \\
\text { for private sector } \\
\text { employees is } 20.6 \% \text {. }\end{array}$ & $\begin{array}{l}\text { Dirección del } \\
\text { Trabajo (2018) }\end{array}$ \\
\hline & Collective bargaining & $\begin{array}{l}\text { Between } 7 \% \text { and } 11 \% \text { of } \\
\text { dependent workers have } \\
\text { collective bargaining }\end{array}$ & $\begin{array}{l}\text { Durán and } \\
\text { Gamonal (2019) }\end{array}$ \\
\hline
\end{tabular}


The second dimension in our proposal is related to social insecurity. This facet is particularly revealing, as one of the main factors for identifying formality under the traditional definition is having social security contributions. However, having everything in the pension system in order may not assure much. Does it provide access to substantive social security? Several reports describe the crisis of the Chilean pension system (Comisión Pensiones, 2015; CNT NO+AFP, 2016; Barriga and Kremerman, 2020); the problems with respect to absolute and relative income sufficiency are clear. As of December 2019, 80 per cent of all pensioners were receiving a pension below minimum wage (Gálvez and Kremerman, 2020). Low pensions can be explained to a large extent by the sporadic nature of contributions, which is often the outcome of discontinuous employment trajectories. But an estimated 50 per cent of new pensioners in 2019, who contributed during thirty to thirty-five years of their working lives, only managed to finance pensions that are on average 78 per cent below minimum wage (Gálvez and Kremerman, 2020). Moreover, in the immediate future (between 2025 and 2035), and with the optimistic scenario of more than thirty-three years of continuous contributions, the estimated median replacement rates for self-financed pensions oscillates between 31 per cent of the pre-retirement salary for women and 42 per cent of the preretirement salary for men (Comisión Pensiones, 2015). Even for people with long-standing formal employment and high contribution density, inadequate results are still likely in terms of relative income sufficiency.

As illustrated in CNT NO+AFP ${ }^{10}$ (2016), one of the big problems with Chile's pension system is that it has systematically violated many of the international principles of social security; hence it cannot be rightly considered a system of social security. Everything seems to indicate that it is a forced system of private savings and individual capitalisation whose primary objective is to inject labour's (financial) capital into large companies, both Chilean and foreign, more than it is to deliver pensions (Gálvez and Kremerman, 2019). Any measure of social security based only on access can thus lead to the wrong conclusions - namely, assuming that something is good or adequate when it probably is not. Based primarily on coverage, Chile ranks among the top ten countries with the best pension systems according to the Mercer Melbourne Global Pension Index (MMGPI).

The third dimension is the wage issue. Half of the workers with formal employment earn less than US \$631 per month (CASEN, 2017), below the family poverty line for a typical household (US \$680 for a four-person household). Hence, although formal employment generally brings higher income than informal employment does, it nonetheless fails to meet the basic income sufficiency test for a significant proportion of people when measured as a function of the cost of living. This is especially marked in the retail sector, the country's largest employer, which constitutes a blatant example of super-exploitation. In this sector, 50 per cent of the formal workforce earns less than US $\$ 552$ per month (CASEN, 2017).

Outside of this sector, wage inconsistency is still a common problem across a range of situations in today's world of work in Chile, and it leads to another issue closely related to financial accumulation. The $8^{\text {th }}$ Family Budget Survey by Chile's National Institute of Statistics (INE) shows that 80 per cent of the population spend more than they earn. People's main expenses are on essential goods, though luxury goods are also part of the picture and becoming more so over time (INE, 2018, see especially graphs 14 and 15). This gap between usual expenses and usual income results in chronic indebtedness. In effect, especially over the last decade, workers have ended up using debt as an extension of their wages (Pérez-Roa, 2019). This creates space for processes that

\footnotetext{
${ }^{10}$ Coordinadora Nacional de Trabajadoras y Trabajadores No más Administradoras de Fondos de Pensiones $=$ National Coordinator of Workers No More Pension Fund Administrators. This is a de facto organisation created by various trade unions, and is an actor in the national debate on pensions in Chile.
} 
use financial instruments to control and discipline the working class (Marambio, 2018).

Our fourth dimension is that of the lack of transparency with regard to the identity of the employer. A clear manifestation of this is the artificial fragmentation in the chains of production within the same group of companies - not only the well-known trend of delocalising and deconcentrating production territorially, but also the use of legal loopholes that conceal the work unit, even in cases in which workers share the same physical space. Supermarkets and department stores are particularly illustrative of this in Chile. The idea is to divide the workforce as much as possible using bureaucratic gymnastics, requiring a legal dispute or major protests to reveal the identity of the actual employer. For example, Durán and Kremerman (2007) show how most large retail companies in Chile aim to block the organisational power of supermarket and department store workers by creating ad hoc legal entities that "administer" small groups instead of large masses. Two models are commonly used to achieve those objectives. In the first, called "employer without sales", the company separates its commercial relationship with its customers from its employment relationship with its workers. Shell companies with no employees handle the business relationships, while a series of companies unrelated to these shell companies are in charge of managing the staff and associated expenses and receive practically no income, with the resulting limitations when demands are made to distribute the profits. In the second model, workers may be employed by different employers, depending on the branch of the supermarket chain in which they work. Although this second model has been losing strength over time due to union reports of employment fraud, it does remain in use in some places even today.

Outsourcing is the second possible manifestation of a lack of transparency with regard to the identity of the employer. This strategy takes on two forms: outsourcing supporting activities and outsourcing core business activities, which can be carried out in a workplace where there is also direct hiring. This creates a triangular employment relationship, with a vague, often conflicting authority and coexisting first- and second-class workers. Outsourced workers tend to experience higher levels of instability, less physical security on the job, lower wages and fewer non-wage benefits. As is the case in other situations, there is a transposition of dimensions that exacerbates the problem. An extreme example of this occurs in mining, where seven out of ten workers are hired by external companies (Sernageomin, 2018). Across the country, 22 per cent of workers covered by the labour code (the most formal workers) were working for outsourcing companies, and in large companies the figure reached 32 per cent (ENE, 2019, our calculation).

Our fifth dimension - occupational risk - involves a range of possibilities. In addition to physical, chemical, biological and ergonomic factors, psychosocial risk factors are on the rise, impacted by the shift to a service economy and by other more interconnected dynamics, such as the instability of contracts and the work intensification caused by performance pressure related to variable pay structures (Pérez-Franco, 2016). In this regard, according to the National Survey on Employment, Work, Health and Quality of Life (ENETS, 2010), three out of ten workers say that most or all of their pay is variable. Multifunctionality is also at play in the intensification of the work day, as tasks are added at will. In the same survey, 74 per cent of people reported that their contracts stipulate carrying out multiple tasks as needed by the company. Finally, there is the problem of paid overtime. The ordinary workday from Monday to Friday is nine hours a day, plus time for lunch, to which extraordinary working hours can be added (up to two hours a day). If we also consider the long commutes many workers face, it is not difficult to understand the sense of suffocation and irritability prevalent within large segments of the population (Araujo and Martuccelli, 2012).

The sixth and final dimension is lack of power, including job-specific conditions as well as 
factors related to organisational capacity. In terms of the latter, Chile has low union density, though this varies across sectors. Overall, the rate of unionisation in the private sector (suggesting formal employment) is close to 20 per cent. However, given the enormous amount of instability, collective agreements are estimated to cover only 10 per cent (Durán and Gamonal, 2019).

In addition to the scarcity of recognised spaces of collective action, the working class also has little power to use the few spaces legally available. Along with other factors, the Plan Laboral from the dictatorship and its continuity in successive neo-liberal governments comes into play here, with its implications for the rules that govern collective agreements, union formation and strikes. With respect to collective agreements, the Chilean state has used its laws to support a high level of decentralisation. Collective agreements are only recognised at the level of the company as an economic unit, defined as a specific legal entity, and they can only be executed by unions constituted at the level of this legal entity. This means that if a de facto business unit chooses to artificially fragment itself into multiple legal entities, workers' ability to associate also becomes atomised. This situation is further exacerbated by a law permitting the constitution of several unions in each legal corporate entity. As a result of this and other atomising factors, there are more than 12000 active trade unions (Dirección del Trabajo, 2018); 50 per cent of currently existing unions have only 40 members or less, and only 1 per cent has more than 1000 members (own calculations based on SIRELA, 2018).

In addition, strikes are restricted in their functioning. Between 1979 and 2016, companies had to meet only basic requirements to be permitted to replace striking workers. Since 2017, a system of "minimal services" has been put in place that can be invoked by any employer, meaning that the notion of essential services promoted by the ILO can be applied to operations even in highly specific sectors. As a result, in contrast to the idea that formal employment (versus informal employment) should create space for larger and more effective struggles for labour improvements, such space in Chile is severely limited.

The distinct dimensions of precarity in formality we have outlined here should not be seen in isolation, as there are significant interconnections among them. In addition, individual work trajectories can move in and out of formality on a frequent basis. Some of this was discussed above when we outlined different possibilities and their mutual relations (Figure 1) and we proposed a way of understanding the six dimensions of precariousness. An extreme case serves to illustrate these interconnections. The agricultural sector has undergone rampant processes of capital concentration and incorporation into the formal wage economy, and work in the sector has become increasingly formal while nonetheless still featuring the highest level of informal occupation, extremely low wages (the lowest after domestic work) and high accident rates. When companies offer employment contracts, they make them as temporary as possible, even when there are longlasting labour relationships. Agricultural employees thus face renewed forms of transience and a combination of old and new forms of legally endorsed wage and organisational restraint. In fact, up to half of their pay can legally be provided as perks, which in some ways goes back to old forms prevalent in captive labour markets. Furthermore, when workers have temporary contracts, which are the predominant form and affect mainly women, their union rights are severely curtailed. The recent labour reform grants all occasional, temporary and seasonal workers the right to collective bargaining, yet it does not recognise their right to trade union immunity or to strike - their tools of pressure. ${ }^{11}$ In other words, it integrates them in a precarious manner. Given their difficult situations, people engage in multiple types of juggling to stabilise or supplement their wages. Valdés

\footnotetext{
${ }^{11}$ Law No. 20,940, published on 8 September 2016 and in effect since 1 April 2017.
} 
(2014) further explores these social and work-related dynamics, identifying the geographic mobility that follows product life cycles across the country, the self-imposed demands necessary due to piecework pay, and the multiple formal and informal activities workers engaged in during months of low activity. These informal activities included:

... setting up food stalls [at neighbourhood markets] during spring festivals, selling used clothes in the parks, drying fruit at the end of the season, filleting fish, working in street vending, knitting, working in construction, farming or as domestic workers or at some emergency municipal job paid at half the minimum wage (Valdés, 2014: 83, free translation).

Workers may have access to some state subsidies to compensate for very low income but as not even the highest wages allow for saving, people go into debt "at the grocery store, with relatives, but above all in the retail chains that go to the workplaces themselves to offer credit cards" (Valdés, 2014: 83, free translation).

The forms of precarity described above can also be grasped by looking at the organised responses emerging from workers. Indeed, the dimension of power can be said to be more important than the other dimensions, and improving it leads indirectly towards deprecarising the other dimensions (an upward movement toward the top half of Figure 1). The following section briefly addresses this movement.

\section{Responses to Precarising Formality}

Although there is a low level of union density within labour formality, and when it does exist it is fragmentary, we are not in a complete wasteland; there are struggles driven by the very workers who seek to address this lack of power. There is a clear movement from the organised working class towards pursuing new forms of organisational power that can dispute control of the labour process. When this happens, advances are made in the direction from the precarious formal pole towards the non-precarious formal pole (top half in Figure 1).

One example of this can be seen in the labour conflicts that emerged around 2006-2007, mainly involving formal precarious workers in global production chains for natural resources and foods. These are the cases of copper workers, forestry workers and salmon workers affected by the proliferation of corporate legal entities. The strength of these conflicts led some authors to suggest we were witnessing the revival of the workers' strike in Chile (Aravena and Núñez, 2009). These experiences of struggle were especially noteworthy because workers, like rarely before, were able to stir up the agenda again after a long decline. As new precarious workers at the core of the economy, it was they who managed to subvert the limits of legality and to dispute corporate power, extra-institutionally, in their actions, despite harsh responses from the business sector and the state (Ponce, 2016). It was formal, precarious workers who revealed the institutional limits of neoliberalism and flexible accumulation.

There are other formal-precarious forms with interesting examples of worker organisation, including conquests that have translated into advances from the formal and precarious towards the formal and less precarious (often only partial progress, but progress nonetheless). Perhaps one of the most relevant cases in recent years - due to its exceptional structural power and the organisational awareness and vigour that have developed around it, with the boost of a de facto union with national reach - has been that of casual workers in the port sector (Santibáñez and Gaudichaud, 2017). 
The case of the Coca-Cola lorry drivers' assistants (peonetas) in Chile is another example of union revitalisation against precarising formality. In their struggle, these workers achieved important gains in two of the dimensions we have looked at: a greater degree of physical job security and increased power to control the work process by means of union organising (Ayala and Ratto, 2018).

Among informal workers in the formal sector there has also been a novel organisational response. Public workers with independent contractor agreements have questioned the state's current forms of hiring, resisted mandatory contributions to the private pension system (that is, resisted precarising formality) and been active participants in the struggle for a new social security system (Araya, 2018; Varas et al., 2018).

At the same time, agribusiness has been witness to the emergence of a broad and flexible organisation of rural and indigenous women (ANAMURI), with an approach that combines diverse horizons and timelines of struggle. They have been waging defensive struggles that seek to put an end to violence against women at work, as well as an end to informal work, the action of intermediaries (outsourcing), the use of pesticides and the attempts to further institutionalise precarity - with the Temporary Worker Statute, for example (Valdés et al., 2012; Valdés, Godoy and Mendoza, 2017). They have also been fighting for different forms of self-management, leading the way to overcoming capitalism and patriarchy.

Finally, and no less important, is the case of the NO+AFP Workers' Coordination - a contemporary milestone in effective organising and mobilising against social insecurity. In this case, still underway, workers and other social organisations are fighting for the class demand of ending the private pension system and establishing a real model of social security (CNT NO+AFP, 2016).

Novelties in the forms of collective action include a significant component of extrainstitutional action, flexibility, mobilising capabilities and ways of working on immediate problems while at the same time addressing broader issues tied to the economic model, the use of natural resources and the role of the state.

Many of these organisations being developed outside of more established unionism are living responses to current contradictions, with a strong territorial and socioenvironmental component. Due to their porosity and elasticity, they have the potential to activate and bring together diverse social subjects, which is significant in the current context of Chile's greatly debilitated unionism.

\section{Synthesis and Final Reflections}

This overview has described some contemporary trends in paid work in Chile, a country with a long neo-liberal history. With a broad focus on precarity, we have presented six dimensions that work against the sustainability of the labour force and tend to situate workers - including those considered protected until recently - in the arena of super-exploitation. We highlight how precarious status is strongly inscribed institutionally due to the insubstantial standard of protection, which, due to efforts to avoid creating large costs for business owners, has led to a convergence in precarity.

The above leads to an analysis of stylised facts. Briefly revisiting two dimensions employment stability and wage consistency - we note that half of all permanent contracts last less than fifteen months, and half of all formal workers earn less than US \$631 a month (US $\$ 400$ net), which means that their employment income is insufficient to bring a typical family out of poverty.

As a paradigm of neo-liberalism and flexible accumulation, the case of Chile suggests that labour formality could become a superfluous category if the current conditions of such formality 
are not examined more carefully. We propose here that formality may indeed have a side - a minority one - that we have called non-precarious formality, but that for the most part it is present as precarising formality. Labour informality coexists with these two categories, and it is wise not to lose sight of it and to review its specificities. Together, the three categories form a system of flows in which workers circulate in a much more volatile context.

Finally, we have also considered that the work setting is a contested space. Among those most affected by precarious formality, there is an active union network, one of the most active even, amid a broader context of fragmentation. On very difficult terrain, there has been a regrowth of organisational networks working to repair the union landscape. Much progress has been made in terms of social organising from below, though there remains a long way to go on the path to a solid, articulated resistance.

\section{References}

Agacino, R. (2006) Hegemonía y contra hegemonía en una contrarrevolución neoliberal madura. La izquierda desconfiada en el Chile post-Pinochet. Working Paper. Buenos Aires: CLACSO.

Agacino, R. and M. Echeverría (eds.) (1995) Flexibilidady condiciones de trabajo precarias. Santiago: Programa de Economía del Trabajo.

Albagli, E., G. Contreras, M. Tapia and J.M. Wlasiuk (2018) Wage Cyclicality of New and Continuing Jobs: Evidence from Chilean Tax Records. Mimeo. Santiago: Central Bank of Chile.

Antunes, R. (1999) ¿Adiós al trabajo? Ensayo sobre las transformaciones y el rol central del mundo del trabajo. Buenos Aires: Antídoto.

Antúnes, R. (2012) The Meanings of Work. Leiden: Brill.

Araujo, K. and D. Martuccelli (2012) Desafios comunes: retrato de la sociedad chilena y sus individuos. Santiago: LOM Ediciones.

Aravena, A. and D. Núñez (2009) El renacer de la buelga obrera en Chile. El movimiento sindical en la primera década del siglo XXI. Santiago: ICAL.

Araya, R. (2018) Los trabajadores del Estado contra el Estado. El conflicto sindical en la Administración Pública durante el Chile de la postdictadura. Historia Regional, 38(1): 1-15.

Ayala, J. and N. Ratto (2018) Estrategias sindicales en dos grandes empresas fragmentadas y filiales de Coca Cola en Chile. Sociol. trab., 94: 63-87.

Barriga, F. and M. Kremerman (2020) Pensiones sin seguridad social ¿Cómo se calcula el monto de las pensiones en Chile? Santiago: Fundación SOL.

Bensusán, G. (2016) Nuevas tendencias en el empleo: retos y opciones para las regulaciones y políticas del mercado de trabajo. Santiago: CEPAL.

Blanco, O. and D. Julián (2019) Una tipología de precariedad laboral para Chile: La precariedad como fenómeno transclasista. Revista de la CEPAL, 129: 99-137.

Castel, R. (2003) From Manual Workers to Wage Laborers: Transformation of the Social Question. New Brunswick, NJ: Transaction Publishers.

Castel, R. (2004) La inseguridad social: ¿Qué es estar protegido? Buenos Aires: Manantial.

Charmes, J. (2019) Dimensions of Resilience in Developing Countries. Cham, Switzerland: Springer.

Chilean Pensions Superintendency (2018) Muestra de datos de Afiliados al Seguro de Cesantía. Base de datos pública. Santiago: Chilean Pensions Superintendency. 
Comisión Pensiones (2015) Informe final comisión asesora presidencial sobre el sistema de pensiones. Santiago: Comisión Asesora Presidencial sobre el Sistema de Pensiones.

Confederación Sindical de Trabajadores y Trabajadoras de las Américas/ Confederación Sindical Internacional.(CSA/CSI) (2013) Tercerización mediante Agencias de Trabajo Temporal en América Latina. Sao Paulo: CSA/CSI

Coordinadora Nacional de Trabajadoras y Trabajadores No más Administradoras de Fondos de Pensiones (CNT NO+AFP) (2016) Nuevo Sistema de Pensiones. Technical Proposal. Santiago: No+AFP National Workers' Coalition.

De la Garza, E. (2000) La flexibilidad del trabajo en América Latina. In Tratado latinoamericano de sociología del trabajo, edited by E. de la Garza. Mexico City: Fondo de Cultura Económica.

De la Garza, E. (2017) Crítica del concepto de informalidad y la propuesta del trabajo no clásico. Trabajo, $9(14): 51-70$.

Dirección del Trabajo (2018) Compendio de Estadísticas Sindicales. Santiago: Labour Directorate.

Dockes, P. and B. Rosier (1981) Crisis y transformación del capitalismo. In Rupturas de un sistema económico, by M. Aglietta et al. Madrid: Blume.

Dörre, K (2010) Social Classes in the Process of Capitalist Landnahme. Socialist Studies, 6(2): 43-74.

Durán, G. (2012) Does Formal Employment Equal Quality Employment in Chile? Working paper for the project Employment Quality in Segmented Markets. Geneva: ILO.

Durán, G. (2015) Formalidad precarizante: impulsando la acumulación de ingresos a través de la desposesión salarial. Paper presented to the conference on "Precariedades, Exclusions, Emergencias", Latin American Studies Association, San Juan, Puerto Rico, 27-30 May 2015.

Durán, G. and S. Gamonal (2019) La opacidad de las cifras: la cobertura de la negociación colectiva en Chile. Derecho y Crítica, 5(1-2): 1-38.

Durán, G. and M. Kremerman (2007) Informe Retail - Capítulo Supermercados y Capítulo Multitiendas. Report prepared for the research department of the Labour Directorate, Chile. Santiago: Fundación SOL.

Durán, G. and M. Kremerman (2020) Los verdaderos sueldos de Chile. Panorama actual del valor de la fuerźa de trabajo usando ESI 2019. Santiago: Fundación SOL.

Echeverría, M. and D. López (2004) Flexibilidad laboral en Chile, las empresas y las personas. Santiago: Research Department, Labour Directorate.

Encuesta de Caracterización Socioeconómica Nacional (CASEN) (2017) Base de microdatos en formato Stata. Santiago: Ministry of Social Development and Family.

Encuesta de Condiciones Laborales (ENCLA) (2019). Labour Force Survey. Santiago: Labour Directorate.

Encuesta Nacional de Empleo (ENE) (2019) Trimestre móvil Julio-Septiembre. Base de microdatos calibrada a nuevos factores de expansion. Santiago: National Institute of Statistics.

Encuesta Nacional de Empleo Trabajo (ENETS) (2010) Salud y Calidad de Vida. Santiago: Ministries of Labour and Health.

Espinosa, M., V. Riquelme, I. Rojas and H. Yañez (1997) Precarización del empleo ¿Un mal moderno? Tema Laboral, 5. Santiago: Labour Directorate.

Faletto, E., E. Ruiz and H. Zemelman (1972) Génesis histórica del proceso político chileno. Santiago: Quimantú.

Fischer, K. (2017) Clases dominantes y desarrollo desigual. Chile entre 1830 y 2010. Santiago: Ediciones Universidad Alberto Hurtado.

Facultad Latinoameericana de Ciencias Sociales (FLACSO) (2017) Determinación de la incidencia del trabajo informal en el ámbito previsional de seguridad social, con enfoque de género. Santiago: FLACSO. 
Fundación SOL (2015) Ser justos es lo primero. La crisis de los trabajadores dominicanos bajo el actual modelo económico. Santo Domingo: Fundación Juan Bosch.

Gálvez, T. (2001) Para reclasificar el empleo. Lo clásico y lo nuevo. Cuaderno de Investigación, 14. Santiageo: Department of Research, Labour Directorate.

Gálvez, R. and M. Kremerman (2019) ¿AFP para quién? Dónde de invierten los fondos de pensiones en Chile. Ideas para el Buen Vivir, 15.

Gálvez, R. and M. Kremerman (2020) Pensiones bajo el minimo. Los montos de las pensiones que paga el sistema de capitalización individual en Chile. Santiago: Estudios de la Fundación SOL.

Gárate, M. (2012) La revolución capitalista de Chile (1973-2003). Santiago: Ediciones Universidad Alberto Hurtado.

Harvey, D. (1992) The Condition of Postmodernity: An Enquiry into the Origins of Cultural Change. Oxford, UK: Blackwell.

Harvey, D. (2003) The New Imperialism. Oxford, UK: Oxford University Press.

Harvey, D. (2005) A Brief History of Neoliberalism. Oxford, UK: Blackwell.

Harvey, D. (2011) The Enigma of Capital and the Crisis of Capitalism. Oxford, UK: Oxford University Press.

Instituto Nacional de Estadística (INE) (2017) Estadísticas de Informalidad Laboral. Santiago: National Institute of Statistics.

Instituto Nacional de Estadística (INE) (2018) Informe de principales resultados VIII Encuesta de presupuestos familiar (EPF). Departamento de Presupuestos Familiares. Santiago: National Institute of Statistics.

International Conference of Labour Statisticians (ICLS) (1993) Informal Sector. Resolution of the 15th International Conference of Labour Statisticians, 19-28 January. Geneva: ILO.

International Conference of Labour Statisticians (ICLS) (2003) Informal Employment. Resolution of the 17th International Conference of Labour Statisticians, 24 November to 3 December. Geneva: ILO.

International Labour Organization (ILO) (1972) Employment, Incomes and Equality. A Strategy for Increasing Productive Employment in Kenya. Geneva: ILO.

International Labour Organization (ILO) (2001) Reducing the Decent Work Deficit: A Global Challenge. Report of the Director General, International Labour Conference, 89th Session. Geneva: ILO.

International Labour Organization (ILO) (2013) Measuring Informality: A Statistical Manual on the Informal Sector and Informal Employment. Geneva: ILO.

International Labour Organization (ILO) (2016) Non-Standard Employment around the World: Understanding Challenges, Shaping Prospects. Geneva: ILO.

International Monetary Fund (IMF) (2014) Chile: Staff Report for the 2014 Article IV Consultation. Washington, DC: IMF.

Julián, D. (2017) Precariedad laboral en América Latina: contribuciones a un modelo para armar, Rev. Colomb. Soc., 40(2): 27-46.

Julián, D. (2018) Precariedad laboral y estrategias sindicales en el neoliberalismo: cambios en la politización del trabajo en Chile. Psicoperspectivas, 17(1): 103-115.

Kalleberg, A.L and S.P. Vallas (eds.) (2018) Precarious Work: Causes, Characteristics, and Consequences. Research in the Sociology of Work Series. Bingley, UK: Emerald Publishing.

Lapavitsas, C. (2009) "Financiarización”, o la búsqueda de beneficios en la circulación. Ekonomiaz, 72: 98119.

López, D. (2008) Subcontratación y conflictos laborales: Un creciente descontento en el trabajo. Santiago: Universidad Central de Chile. 
Marambio, A. (2018) Crédito y endeudamiento de hogares: sobre la economía moral del proletariado postindustrial en Chile. In La constitución social, política y moral de la economía cbilena, edited by F. González and A. Madariaga. Santiago: RIL Editores.

Marini, R.M. (1991) Dialéctica de la dependencia. Mexico City: Era.

Narbona, K. (2015a) Antecedentes del Modelo de Relaciones Laborales chileno. Santiago: Observatorio Social del Proyecto Plataformas Territoriales por los derechos Económicos y Sociales.

Narbona, K. (2015b) ¿Pleno empleo o pleno empleo precario? Las tendencias de precarización del empleo en Chile y sus bases económicas e institucionales. In Las implicancias de la expansión del empleo precario para la organización y acción sindical, edited by S. Yañez and K. Narbona. Santiago: FLACSO.

Narbona, K. (2016) Una aproximación a la precariedad laboral en Chile: situación actual y antecedentes históricos. Paper presented at the conference "Estudios de Informalidad, Precariedad y Trabajo Atípico". Grupo de Estudios del Trabajo desde el Sur, Temuco, 5-7 December.

Narbona, K. and A. Páez (2014) La acumulación flexible en Chile: Aportes a una lectura socio-histórica de las transformaciones recientes del trabajo. Revista Pretérito Imperfecto, 2(1): 140-172.

Neffa, J.C. (1985) Reflexiones acerca del empleo precario. Proceedings of the Asociación Argentina de Economía Política, $20^{\text {th }}$ Annual Meeting, Faculty of Economics, Universidad Nacional de Cuyo, Argentina, 6-8 November.

Neffa, J.C. (2010) La transición de los verdaderos empleos al empleo precario. In Trabajo, identidad y acción colectiva, edited by E. de la Garza and J.C. Neffa. Mexico City: CLACSO/UNAM.

Osorio, J. (1975) Superexplotación y clase obrera: el caso mexicano. Cuadernos Políticos, 6 (Oct-Dec): 5-23.

Pérez-Franco, J. (2016). Nuevos trabajos, nuevos riesgos. Chile y los factores de riesgo psicosocial laboral. Revista Chilena de Salud Pública, 20(1): 36-44.

Pérez-Roa, L. (2019) Consumo, endeudamiento y economía doméstica: una historia en tres tiempos para entender el estallido social. In Hilos tensados. Para leer el octubre chileno, edited by K. Araujo. Santiago: Editorial USACH.

Ponce, J. (2016) Oportunidad, conflicto y reconocimiento: El movimiento de trabajadores subcontratados de CODELCO y el Gobierno de Michelle Bachelet, 2006-2007. Izquierdas, 29: 106-132.

Portes, A. (1995) En torno a la informalidad. Mexico City: FLACSO-PORRÚA.

Prebisch, R. (1950) The Economic Development of Latin America and its Principal Problems. Santiago: ECLAC.

Reinprecht, C. (2011) El regreso de la inseguridad social. Nueva Sociedad, 232: 26-30.

Rodgers, G. and J. Rodgers. (1989) Precarious Jobs in Labour Market Regulation. The Growth of Atypical Employment in Western Europe. Brussels: International Institute for Labour Studies/Free University of Brussels.

Rojas, I. (2007) Las reformas laborales al modelo normativo de negociación colectiva del Plan Laboral. Revista Ius Et Praxis, 13(2): 195-221.

Sáez, P (2013) Empleo informal y precariedad en el Chile actual. Thesis in application for the professional degree of Bachelor of Sociology, Universidad de Chile, Santiago.

Santibáñez, C. and F. Gaudichaud (2017) Los obreros portuarios y la idea de "posición estratégica" en la postdictadura chilena (2003-2014). In Trabajadores y trabajadoras. Procesos y acción sindical en el neoliberalismo cbileno (1979-2017), edited by J. Ponce, C. Santibáñez and J. Pinto. Valparaíso: América en Movimiento.

Sehnbruch, K. (2013) La calidad del empleo en Chile: entre teoría y medición. In La calidad del empleo en América Latina, edited by S. Farné. Bogotá: Universidad Externado de Colombia.

Sernageomin (2018) Anuario de la Minería de Chile 2018. Santiago: Servicio Nacional de Geología y Minería.

Sistema Informático de Relaciones Laborales (SIRELA) (2018). Base de datos on-line sobre sindicatos en Chile, Dirección del Trabajo. 
Sotelo, A. (2003) La reestructuración del mundo del trabajo, superexplotación y nuevos paradigmas de la organización del trabajo. Mexico City: Universidad Obrera de México.

Standing, G. (1999) Global Labour Flexibility: Seeking Distributive Justice. Basingstoke: Macmillan.

Standing, G. (2011) The Precariat: The New Dangerous Class. London: Bloomsbury.

Streeck, W. (2014) Buying Time: The Delayed Crisis of Democratic Capitalism. London: Verso.

Tokman, V. (1995) El sector informal en América Latina: dos décadas de análisis. Mexico City: Consejo Nacional para la Cultura y las Artes.

Valdés, X. (2014) Trabajo agrícola temporal, familias, géneros. In Trabajos y familias en el neoliberalismo. Hombres y mujeres en faenas de la wva, el salmón y el cobre, edited by X. Valdés, L. Rebolledo, J. Pavez and G. Hernández. Santiago: LOM Ediciones.

Valdés, X., C. Godoy, A. López and P. Raposo (2012) De la sindicalización campesina al estatuto del temporero. Pasado y presente en las luchas de los trabajadores agrícolas. Espacios, 2(4): 71-87.

Valdés, X., C. Godoy and A. Mendoza (2017) Acción colectiva y resistencia: asalariadas agrícolas en Chile frente a la precarización laboral. Irquierdas, 35(September): 167-198.

Varas, A., A. Carrasco, D. Gutiérrez and A. Bascuñan (2018), La explotación del "área social”, una lectura de la precariedad laboral del tercer sector en Chile desde el Capital de Marx. Irquierdas, 39: 273-298.

Vives-Vergara, A., F. González-López, O. Solar, P. Bernales-Baskai, M.J. González and J. Benach (2017) Precariedad laboral en Chile: propiedades psicométricas de la versión chilena de la Escala de Precariedad Laboral en trabajadores del sector privado. Cad. Saúde Pública, 33(3): e00156215.

Vives, A., F. González-López and J. Benach (2020) Measuring Precarious Employment: Type of Contract can Lead to Serious Misclassification Error. Annals of Work Exposures and Health, 64(9): 1035-1038. DOI: 10.1093/annweh/wxaa089.

\section{BIOGRAPHICAL NOTES}

GONZALO DurÁn is a PhD candidate at the University of Duisburg-Essen, Germany, and an economist at Fundación SOL in Santiago, Chile. [Email: giduran@puc.cl]

KARINA NARbONA is a PhD candidate at the University of Cologne, Germany, and a social anthropologist at Fundación SOL in Santiago, Chile. [Email: karina.narbona@,fundacionsol.cl] 